\title{
Genes for L-Sorbose Utilization in Escherichia coli
}

\author{
By M. J. WOODWARD*† AND H. P. CHARLES \\ Department of Microbiology, University of Reading, London Road, Reading RG1 SAQ, U.K.
}

(Received 5 January 1982; revised 29 January 1982)

\begin{abstract}
Amongst forty wild strains of Escherichia coli, nine used L-sorbose as a source of carbon and energy and two mutated to use it. Laboratory strains K12, B and C were L-sorbose-negative. Genes for L-sorbose utilization $\left(\right.$ sor $\left.^{+}\right)$were transferred to $\mathrm{K} 12$ from six wild strains; genes conferring the mutable phenotype were also transferred. All were cotransducible with met $A$ at 90 min on the linkage map. The most probable gene order was met ace sor pgi mal. Complementation tests identified two genes for L-sorbose utilization. Genetical evidence showed that the catabolite repressor protein of $\mathrm{K} 12$ exerted positive control over sor ${ }^{+}$genes introduced into K12. The genes for phosphofructokinase $(p f k A)$, the phosphocarrier protein $(p t s H)$ and phosphotransferase enzyme I ( $p t s I$ ) were required for utilization of L-sorbose.

The frequency of transduction of sor $^{+}$was low when selection was made for sor $^{+}$, because Lsorbose partially inhibited the growth of both L-sorbose-negative strains and K12 (sor $\left.{ }^{+}\right)$strains. Uridine, thymidine and sorbitol each annulled the inhibition of growth and increased the frequency of transduction of sor ${ }^{+}$.
\end{abstract}

\section{INTRODUCTION}

Alaeddinoglu \& Charles (1979) confirmed the observation of Edwards \& Ewing (1972) that about $50 \%$ of Escherichia coli strains, including K12, do not use sucrose. Transferred from a wild strain, the genes for sucrose utilization $\left(\mathrm{sac}^{+}\right)$were located at $50.5 \mathrm{~min}$ on the $\mathrm{K} 12$ linkage map. Hill (1980) and Hill \& Charles (1980) showed that $\mathrm{sac}^{+}$genes from twenty wild strains, and sac genes from wild strains that mutated to use sucrose, had the same location in $\mathrm{K} 12$, as judged by simple cotransduction tests. Only in occasional strains were genes for sucrose utilization carried by plasmids. Woodward (1980) and Woodward \& Charles $(1980 a, b)$ set out to test whether genetical variation shown by other characters followed similar rules. Firstly, characters were transferred to $\mathrm{K} 12$ for ease of genetic analysis. The choice of characters was limited by the requirement for clear distinction between the different states of a character occurring in nature, and by the requirement that one state, usually the positive one, was easily selectable in transduction and conjugation experiments; it was also necessary that $\mathrm{K} 12$ be naturally negative for the character, to permit transfer to K12. Only characters specified by chromosomal genes were studied in detail, on the supposition that variation due to chromosomal genes might reflect less ephemeral selective effects in nature than variation due to the presence and absence of plasmids.

One character, L-sorbose utilization, gave results partly similar to those obtained for sucrose utilization (Woodward \& Charles, 1980a). The characters of ribitol and D-arabitol utilization, on the one hand, and galactitol utilization on the other, exhibited a rather different situation in that their genes behaved as alternatives in the K12 chromosome (Woodward, 1980; Woodward \& Charles, $1980 \mathrm{~b}$ ). The results obtained for the $\mathrm{L}$-sorbose character are now presented. Genes specifically concerned with L-sorbose utilization are denoted sor.

\section{METHODS}

The methods used followed Alaeddinoglu \& Charles (1979), except when stated otherwise.

Media. Glucose tetrazolium indicator medium was as described by Epstein et al. (1970).

† Address for correspondence: 7A Woodcote Lawns, Chesham, Bucks HP5 2LY, U.K. 
Table 1. Escherichia coli strains

Strain

Genotype

\begin{tabular}{|c|c|}
\hline AB468 & $\mathrm{F}^{-}$proA2 lacY galK2 his-4 xyl mtl thi-1 purD \\
\hline $\mathrm{AB} 1621$ & $\mathrm{~F}^{-}$ara lac tsx gal rpsL xyl mtl glpD thiA \\
\hline AB2569 & $\mathrm{F}^{-}$proA2 lac $Y$ galK2 his-4 xyl mtl thi- 1 argE met $A$ \\
\hline FF8020 & $\mathrm{F}^{-}$proC $\mathrm{ptsH}$ rpsL \\
\hline FF8040 & $\mathrm{F}^{-}$proC ptsI rpsL \\
\hline JC1553 & $\mathrm{F}^{-}$leu his recA rpsL malA argG metB \\
\hline MLM161 & $\mathrm{F}^{-}$his rpsL mal mtl ilv metB glpK arg $H$ \\
\hline PC0132 & $\mathrm{F}^{-}$lacY gal-3 rpsL malA xyl mtl thi-1 purH47 \\
\hline WA 802 & $\mathrm{~F}^{-}$lac Y galK2 galT22 hsdR2 metB \\
\hline WA803 & $\mathrm{F}^{-}$lac $Y$ galK2 galT22 hsdS3 met $B$ \\
\hline $2 \mathrm{~K}$ & $\mathrm{~F}^{-}$lac $Y$ hsd $S 918$ rpsL thi-1 $\operatorname{ser} B$ \\
\hline $5 \mathrm{~K}$ & $\mathrm{~F}^{-}$thr-1 leu-6 lac Y tonA21 hsdR514 rpsL thi-1 \\
\hline AB347 & VHfr $t h r-1$ leu-6 ara-2 lacZ4 aroC4 rpsL thi-1 \\
\hline AB2575 & Hfr tsx ilv thiA \\
\hline AM1 & $\mathrm{Hfr}$ tonA22 relAl pfkA1 \\
\hline AT997 & $\mathrm{Hfr}$ dapC relA thi-1 \\
\hline DF40 & Hfr tonA 22 relA1 pgi-2 \\
\hline KG1673 & Hfr thi-l \\
\hline R4 & Hfr relAl met $B 1$ \\
\hline $5333 S$ & $\mathrm{Hfr} r p s L$ crp \\
\hline MW4 & sor $^{+}$transductant of strain $\mathrm{R} 4$, donor MW871 \\
\hline MW5 & $\begin{array}{l}\text { sac }^{+} \text {transductant of strain MW4, donor GA122 } \\
\text { (Alaeddinoglu \& Charles, 1979) }\end{array}$ \\
\hline MW284 & $\begin{array}{l}\text { ace } 284 \text { mutant of strain DF } 40 \text { made by MNNG } \\
\text { mutagenesis }\end{array}$ \\
\hline MW285 & sor $^{+}$transductant of strain MW284, donor MW871 \\
\hline MW871-878 & sor $^{+}$transductants of strain $\mathrm{AB} 1621$, donor RK87 \\
\hline MW951-953 & sor $^{+}$transductants of strain AB1621, donor RK 95 \\
\hline MW3016 & $\begin{array}{l}\text { mal-3016 mutant of strain AB2569 made by MNNG } \\
\text { mutagenesis }\end{array}$ \\
\hline MW3017 & sor $^{+}$transductant of strain MW3016, donor MW871 \\
\hline MW5752 & sor $^{+}$transductant of strain AB2575, donor MW871 \\
\hline MWSN50-75 & $\begin{array}{l}\text { sor mutants of strain MW5752 made by MNNG } \\
\text { mutagenesis }\end{array}$ \\
\hline MWSN $3050-75$ & $\begin{array}{l}\text { met }^{+} \text {sor transductants of strain MW3017, donors } \\
\text { were MWSN50-75 respectively }\end{array}$ \\
\hline RK $1-120$ & Wild strains isolated from the River Kennet \\
\hline
\end{tabular}

\section{Reference}

Stouthamer et al. (1965)

Adelberg et al. (1965)

Eggertsson \& Adelberg (1965)

Epstein et al. (1970)

Epstein et al. (1970)

Clark \& Marguiles (1965)

McConville \& Charles (1979)

Stouthamer et al. (1965)

Wood (1966)

Wood (1966)

Colson et al. (1965)

Colson et al. (1965)

Huang \& Pittard (1967)

Pittard et al. (1963)

Morrisey \& Fraenkel (1968)

Bukhari \& Taylor (1971)

Fraenkel \& Levisohn (1967)

Kawasaki et al. (1968)

Reeves (1959)

Epstein \& Kim (1971)

This work

This work

This work

This work

This work

This work

This work

This work

This work

This work

This work

This work

Lysogenization and transduction by Plclrl00KM. These were as described by Goldberg et al. (1974). An improved method of lysogenization is described in the text.

Conjugation. For VHFr AB347, chromosome transfer was stopped by lysis from without, using phage T6; samples $(0 \cdot 1 \mathrm{ml})$ of plating mixture were diluted in $0.9 \mathrm{ml}$ of a solution containing $0 \cdot 1 \mathrm{M}-\mathrm{MgSO}_{4}, 0.02 \mathrm{M}-\mathrm{CaCl}$, DLtryptophan $\left(4 \mathrm{mg} \mathrm{l}^{-1}\right)$ and $10^{8}$ infective phage $\mathrm{T} 6$. Lysis was at $37^{\circ} \mathrm{C}$ for $15 \mathrm{~min}$. Recipients were $t s x$.

Gene symbols and map distances. These follow Bachmann \& Low (1980). By agreement with Dr Bachmann the genes for L-sorbose transport and L-sorbose utilization are given the symbols $\operatorname{sor} T^{+}$and $\operatorname{sor} A^{+}$, respectively.

Strain designations and genotypes. These are shown in Table 1. Strain MW284 was made by mutagenesis of strain DF40; the new allele ace-284 was similar to the ace $A$ and $a c e B$ alleles (Brice \& Kornberg, 1968) in blocking acetate utilization; cotransduction frequencies of $86 \%$ with met $A$ and of $42 \%$ with pgi were close to those obtained by Vanderwinkel \& de Vlieghere (1968). Strain MW3016 was made by mutagenesis of strain AB2569; the new allele mal-3016 generated the malB phenotype described by Hofnung et al. (1974); cotransduction frequencies of $10 \%$ with $m e t A$ and of $47 \%$ with pgi were close to those obtained for malB by Kadner \& Liggins (1973).

\section{RESULTS}

\section{Transfer to K12 of the ability to use L-sorbose}

Escherichia coli $\mathrm{K} 12$ strains did not use L-sorbose as a carbon and energy source and did not mutate to use it. Of forty wild strains streaked on L-sorbose minimal medium, nine used Lsorbose and two gave L-sorbose-positive mutant colonies against a background of L-sorbose- 
negative bacteria. Because no wild strains gave plaques with phage $P 1$, attempts were made to lysogenize the L-sorbose-positive strains with phage P1clr100KM (Goldberg et al., 1974), as a preliminary to transduction. Lysogens were selected by their kanamycin resistance, and lysogeny was confirmed by lysis at $42{ }^{\circ} \mathrm{C}$ and liberation of phage. Strains RK87 and RK95 were readily lysogenized, but other strains did not give lysogens. Induction at $42{ }^{\circ} \mathrm{C}$ gave lysates $\left(10^{9}\right.$ phage $\mathrm{ml}^{-1}$ ) which were used to transduce AB1621 ( $\left.x y l\right)$, selection being made separately for transductants able to use L-sorbose and xylose. Selection for $x y l^{+}$served as a positive control measuring transducibility of a gene common to $\mathrm{K} 12$ and the donors. The $x y l^{+}$transductants occurred with a frequency of 1 per $4 \times 10^{6}$ phage, and were scoreable after $2 \mathrm{~d}$. Strain RK87 gave eight Sor ${ }^{+}$transductants from $10^{9}$ phages, and RK95 gave three Sor ${ }^{+}$transductants from $10^{9}$ phages, all scoreable after $5 \mathrm{~d}$. The Sor ${ }^{+}$transductants were given the designations MW871 to MW878, and MW951 to MW953, respectively. Apart from being Sor ${ }^{+}$, transductants retained characters typical of $\mathrm{AB} 1621$. They differed from the wild donors in requiring $5 \mathrm{~d}$, rather than $2 \mathrm{~d}$, to give colonies of $2 \mathrm{~mm}$ diameter on L-sorbose minimal medium.

The possibility that $\mathrm{K} 12$ bacteria might mutate to use L-sorbose was checked carefully. A large number of varied tests all failed to give K12 mutants able to use L-sorbose. Tests included treatments with nine common chemical mutagens, UV irradiation, incubation for long periods in peptone broth containing L-sorbose, and incubation in L-sorbose medium containing bile salts, since Coetzee (1962) found that bile salts increased the permeability of Proteus to sucrose.

Tests were made to see whether ability to utilize L-sorbose was due to plasmids. Cells of $E$. coli $\mathrm{K} 12$ were incubated with $\mathrm{Sor}^{+}$wild strains and with $\mathrm{Sor}^{+}$mutants of the two mutable strains. The $\mathrm{K} 12$ recipients in different experiments were $\mathrm{AB} 1621,2 \mathrm{~K}, 5 \mathrm{~K}$, WA802 and WA803, selection being made for Sor ${ }^{+}$transconjugants resistant to streptomycin. The Sor ${ }^{+}$character was not transferred in these tests, nor was it lost from wild strains on treatment with sodium lauryl sulphate (Tomoeda et al., 1968) or acridine orange (Salisbury et al., 1972) by methods which removed plasmids from K12 (Alaeddinoglu \& Charles, 1979).

\section{Gene order}

Using hybrid MW871 as donor, Hfr strains KG1673, AB347, AT997 and AB2575 were transduced to Sor ${ }^{+}$. In time-of-transfer experiments, the Hfr strains transferred their sor ${ }^{+}$ regions after 20, 30, 75 and 100 min respectively, indicating a locus in the 89-91 min region near malB (Hofnung et al., 1974). Tests were made for cotransduction of sor ${ }^{+}$with the wild-type alleles of $\operatorname{argH}, \operatorname{pur} H$, purD, metA, ace-284, pgi and mal-3016, which occur in that order on the linkage map, from 89 to $91 \mathrm{~min}$, with certain genes omitted. In each transduction, selection was made separately for sor $^{+}$and wild-type allele of the relevant marker gene, with the exception that $p g i^{+}$was not selectable. Cotransduction of $p g i^{+}$was tested by streaking sor ${ }^{+}$transductants on glucose tetrazolium indicator medium: $p g i^{+}$bacteria gave pale pink colonies and pgi bacteria gave dark red colonies (Fraenkel \& Levison, 1967). In each cross, selection for sor $^{+}$gave less than one-twentieth the transductants given by the other selection (Table 2 ). The sor region was cotransduced with all the markers, most frequently with $p g i^{+}, a c e-284^{+}$and $\mathrm{mal}^{-3016^{+}}$. MW285 (ace-284 sor ${ }^{+}$pgi) was then used as donor is transduction with MW3016 (metA mal-3016), selections being made for sor $^{+}$and met $^{+}$. The results in Table 3 show that the gene order was probably met ace sor ${ }^{+}$pgi mal. The other ten $\mathrm{K} 12\left(\mathrm{sor}^{+}\right)$hybrids were tested in critical transductions (Table 4) and gave evidence for a constant locus for sor ${ }^{+}$.

Comparisons of cotransduction frequencies for the pairs of alleles metA-ace-284, metA-pgi and metA-mal-3016 were made using as donors a K12 strain (MW284) and a $\mathrm{K} 12$ (sor ${ }^{+}$) hybrid (MW285). The recipient was MW3016 and selection was made in each case for met $^{+}$. Cotransduction frequencies $(\%)$ were 82.5 and 85,18 and $21 \cdot 6$, and 8 and $9 \cdot 8$, respectively.

The transductants selected for sor ${ }^{+}$in Table 3 were tested to see whether they might be unstable partial diploids. To determine their genotypes, the transductants had first been streaked on the selective medium, then patched on the same medium and replicated on to other media. One colony from each of the 527 streaks was restreaked four times on the same medium containing L-sorbose, methionine and uridine (see below). Forty-three transductants gave 
Table 2. Cotransduction frequencies in the sor $^{+}$region (donor strain MW871)

\begin{tabular}{|c|c|c|c|c|c|}
\hline Recipient & $\begin{array}{c}\text { Allele } \\
\text { generating } \\
\text { selected } \\
\text { phenotype }\end{array}$ & $\begin{array}{c}\text { Transductants } \\
\text { per } \\
10^{8} \text { phage }\end{array}$ & $\begin{array}{l}\text { No. } \\
\text { scored }\end{array}$ & $\begin{array}{l}\text { Unselected } \\
\text { donor } \\
\text { allele } \\
\text { scored }\end{array}$ & $\begin{array}{c}\text { Contransduction } \\
\text { frequency }(\%)\end{array}$ \\
\hline \multirow[t]{2}{*}{ MLM161 } & sor $^{+}$ & 10 & 210 & $\arg H^{+}$ & 0 \\
\hline & $\arg H^{+}$ & 200 & 1321 & sor $^{+}$ & $1 \cdot 5$ \\
\hline \multirow[t]{2}{*}{ PCO132 } & sor $^{+}$ & 8 & 55 & purH $H^{+}$ & 9 \\
\hline & pur $H^{+}$ & 200 & 164 & sor $^{+}$ & 22 \\
\hline \multirow[t]{2}{*}{ AB468 } & sor $^{+}$ & 10 & 79 & purD $D^{+}$ & 11 \\
\hline & purD $D^{+}$ & 150 & 246 & sor $^{+}$ & 28 \\
\hline \multirow{2}{*}{ AB2569 } & sor $^{+}$ & 20 & 90 & $\operatorname{met}^{+}$ & 15 \\
\hline & $\operatorname{met}^{+}$ & 300 & 237 & sor $^{+}$ & 34 \\
\hline \multirow[t]{2}{*}{ MW284 } & sor $^{+}$ & 30 & 67 & $a c e^{+}$ & 24 \\
\hline & $a c e^{+}$ & 100 & 124 & sor $^{+}$ & 47 \\
\hline DF40 & sor $^{+}$ & 10 & 100 & $p g i^{+}$ & 77 \\
\hline \multirow[t]{2}{*}{ MW3016 } & $\mathrm{mal}^{+}$ & 40 & 230 & sor $^{+}$ & 16 \\
\hline & sor $^{+}$ & 6 & 40 & $\mathrm{mal}^{+}$ & 34 \\
\hline
\end{tabular}

Table 3. Evidence from transduction for the position of sor ${ }^{+}$

The donor was MW285 (metA aceAB sor $^{+}$pgimalB ${ }^{+}$) and the recipient was MW3016 ( $m e t A$ ace $A B^{+}$pgi $^{+}$malB); sor ${ }^{+}$is shown in its most probable position relative to the known sequence of marker genes. Unselected donor markers
received when selection was for sor ${ }^{+*}$

$\begin{array}{ccc} & & \\ {\text { met } A^{+}}^{+} & \text {ace } & \text { sor } \\ - & - & \mathrm{S} \\ - & - & \mathrm{S} \\ - & - & \mathrm{S} \\ + & + & \mathrm{S} \\ - & + & \mathrm{S} \\ + & + & \mathrm{S} \\ - & + & \mathrm{S} \\ + & + & \mathrm{S} \\ - & + & \mathrm{S} \\ + & - & \mathrm{S} \\ - & - & \mathrm{S} \\ + & - & \mathrm{S} \\ - & + & \mathrm{S} \\ + & - & \mathrm{S} \\ + & - & \mathrm{S} \\ + & + & \mathrm{S}\end{array}$

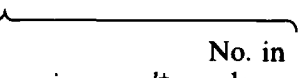

pgi $\mathrm{mal}^{+} \begin{gathered}\text { No. in } \\ \text { class }\end{gathered}$

- $\quad-\quad 156$

$+\quad+\quad 123$

$+\quad-\quad 106$

- $\quad-\quad 28$

$-\quad-\quad 26$

$\begin{array}{rr}- & 26 \\ +\quad 17\end{array}$

$+\quad+16$

$\begin{array}{rr}+ & 16 \\ +\quad+\quad 13\end{array}$

$\begin{array}{rrr}+ & + & 13 \\ + & - & 13\end{array}$

$+\quad+9$

$\begin{array}{lll}+ & + & 9 \\ - & + & 6\end{array}$

$+\quad-4$

$\begin{array}{lll}+ & - & 4 \\ - & + & 4\end{array}$

$\begin{array}{lll}- & + & 4 \\ - & - & 4\end{array}$

$\begin{array}{lll}- & 4 \\ - & + & 1\end{array}$
Unselected donor markers received when selection was for met $^{+\dagger}$

$\mathrm{S}$, selected marker; +, unselected donor marker received; - , unselected recipient marker retained.

* Transduction frequency 1 per $2 \times 10^{6}$ phage.

$\dagger$ Transduction frequency 1 per $10^{6}$ phage.

microcolonies on each successive streak: microcolonies were tiny translucent colonies less than $0.5 \mathrm{~mm}$ in diameter, quite unlike the $2 \mathrm{~mm}$ opaque colonies which largely made up the streak. About one microcolony was present for every 200 large colonies on a streak. Transductants that gave microcolonies all belonged to the class of 156 in which only the Sor ${ }^{+}$character from the donor had been received.

\section{Transduction of the sor regions from six more wild strains}

Several attempts were made to lysogenize strains which were not lysogenized by the standard method. Schell \& Glover $(1966 a, b, c)$ described treatments which decreased the restriction 
Table 4. Cotransduction of two markers with sor ${ }^{+}$using 10 different $K 12$ (sor $\left.{ }^{+}\right)$hybrids as donors

Selection was for sor ${ }^{+}$. The recipient was MW3016 (metA mal-3016). Donor strains MW872 to 878, and MW951 to 953 contained sor $^{+}$regions from wild strains RK87 and RK95, respectively.

\begin{tabular}{|c|c|c|c|c|}
\hline Donor & $\begin{array}{c}\text { Transductants } \\
\text { per } \\
10^{8} \text { phage }\end{array}$ & $\begin{array}{l}\text { No. } \\
\text { scored }\end{array}$ & $\begin{array}{c}\text { Allele } \\
\text { generating } \\
\text { unselected } \\
\text { phenotype }\end{array}$ & $\begin{array}{l}\text { Cotransduction } \\
\text { frequency }(\%)\end{array}$ \\
\hline MW872 & 10 & 97 & $\begin{array}{l}\mathrm{metA}^{+} \\
\mathrm{mal}^{+}\end{array}$ & $\begin{array}{l}32 \\
35\end{array}$ \\
\hline MW873 & 20 & 83 & $\begin{array}{l}\mathrm{metA}^{+} \\
\mathrm{mal}^{+}\end{array}$ & $\begin{array}{l}24 \\
33\end{array}$ \\
\hline MW874 & 8 & 79 & $\begin{array}{l}\mathrm{metA}^{+} \\
\mathrm{mal}^{+}\end{array}$ & $\begin{array}{l}24 \\
34\end{array}$ \\
\hline MW875 & 7 & 101 & $\begin{array}{l}\mathrm{metA}^{+} \\
\mathrm{mal}^{+}\end{array}$ & $\begin{array}{l}14 \\
36\end{array}$ \\
\hline MW876 & 6 & 71 & $\begin{array}{l}\mathrm{metA}^{+} \\
\mathrm{mal}^{+}\end{array}$ & $\begin{array}{l}21 \\
30\end{array}$ \\
\hline MW877 & 6 & 65 & $\begin{array}{l}\mathrm{metA}^{+} \\
\mathrm{mal}^{+}\end{array}$ & $\begin{array}{l}20 \\
26\end{array}$ \\
\hline MW878 & 10 & 93 & $\begin{array}{l}\mathrm{metA}^{+} \\
\mathrm{mal}^{+}\end{array}$ & $\begin{array}{l}28 \\
28\end{array}$ \\
\hline MW951 & 10 & 91 & $\begin{array}{l}\mathrm{metA}^{+} \\
\mathrm{mal}^{+}\end{array}$ & $\begin{array}{l}19 \\
31\end{array}$ \\
\hline MW952 & 15 & 93 & $\begin{array}{l}\mathrm{metA}^{+} \\
\mathrm{mal}^{+}\end{array}$ & $\begin{array}{l}17 \\
33\end{array}$ \\
\hline MW953 & 15 & 102 & $\begin{array}{l}\mathrm{metA}^{+} \\
\mathrm{mal}^{+}\end{array}$ & $\begin{array}{l}19 \\
32\end{array}$ \\
\hline
\end{tabular}

Table 5. Isolation of PIclr100KM lysogens of E. coli wild strains

In method (i) $10^{9}$ bacteria were mixed with $2.5 \times 10^{9}$ phage and plated as described by Goldberg $e t$ al. (1974); method (iii) is described in the text, and method (ii) was method (iii) without the period for expression of kanamycin resistance.

No. of presumptive lysogens obtained per $10^{9}$ bacteria

\begin{tabular}{lccr} 
& \multicolumn{3}{c}{$\begin{array}{c}\text { Method: } \\
\text { (ii) }\end{array}$} \\
Strain & (i) & NT & (iii) \\
RK87 & 489 & NT & NT \\
RK95 & 578 & $3^{*}$ & NT \\
RK43 & 0 & $14^{*}$ & 417 \\
RK53 & $10^{*}$ & $67^{*}$ & 952 \\
RK79 & $6^{*}$ & 0 & 2041 \\
RK99 & 0 & 0 & 184 \\
RK107 & $1^{*}$ & 0 & 104 \\
RK119 & $5^{*}$ & 0 & 159 \\
RK2 & 0 & 0 & 0 \\
RK27 & 0 & & 0
\end{tabular}

NT, Not tested.

* Did not lyse at $42^{\circ} \mathrm{C}$; probably spontaneous kanamycin-resistant mutants.

endonuclease activity of $\mathrm{K} 12$ and allowed phage from $E$. coli $\mathrm{C}$ to give more plaques on $\mathrm{K} 12$. Adaptation of their methods gave P1clr100KM lysogens of six more wild strains. Overnight cultures in complete medium were washed twice, incubated in $0.01 \mathrm{M}-\mathrm{MgSO}_{4}$ solution $\left(37^{\circ} \mathrm{C}\right.$, $1 \mathrm{~h}$ ), incubated in fresh $\mathrm{MgSO}_{4}$ solution $\left(49.5^{\circ} \mathrm{C}, 1 \mathrm{~h}\right)$, resuspended in a solution of $0.01 \mathrm{M}$ $\mathrm{MgSO}_{4}$ and $0.02 \mathrm{M} \mathrm{CaCl}_{2}$ with the phage at a multiplicity of infection of $2.5\left(30^{\circ} \mathrm{C}, 30 \mathrm{~min}\right)$ and diluted with complete medium $(5: 1, \mathrm{v} / \mathrm{v})$. Suspensions were then incubated at $30^{\circ} \mathrm{C}$ for $40 \mathrm{~min}$ to allow phenotypic expression of kanamycin resistance and plated on complete medium supplemented with kanamycin $\left(12.5 \mathrm{mg}^{-1}\right)$. Results for the three methods are shown in Table 5. 
Table 6. Testing of met $A^{+}$transductants given by six wild donors, for cotransduction of sor ${ }^{+}$ (or sor $\left.{ }^{\mathrm{m}}\right)^{*}$ and $\mathrm{mal}^{-3016^{+}}$

Selection was made for $m e t A^{+}$, using strain MW3016 (met A mal-3016) as recipient. Transductants from mutable donors were streaked and incubated on L-sorbose minimal medium for $14 \mathrm{~d}$ to test for ability to mutate to use L-sorbose.

\begin{tabular}{|c|c|c|c|c|c|}
\hline Donor & $\begin{array}{c}\text { Phage } \\
\text { titre } \\
\text { on } \\
\text { Strain } 5 \mathrm{~K}\end{array}$ & $\begin{array}{l}\text { Transductants } \\
\text { per } 10^{7} \text { phage }\end{array}$ & $\begin{array}{l}\text { No. } \\
\text { scored }\end{array}$ & $\begin{array}{c}\text { Allele } \\
\text { generating } \\
\text { unselected } \\
\text { phenotype }\end{array}$ & $\begin{array}{c}\text { Cotransduction } \\
\text { frequency }(\%)\end{array}$ \\
\hline RK 43 & $5 \times 10^{7}$ & 5 & 48 & $\begin{array}{l}\mathrm{sor}^{+} \\
\mathrm{mal}^{+}\end{array}$ & $\begin{array}{l}25 \\
15\end{array}$ \\
\hline RK 79 & $7 \times 10^{7}$ & 2 & 19 & $\begin{array}{l}\mathrm{sor}^{+} \\
\mathrm{mal}^{+}\end{array}$ & $\begin{array}{l}37 \\
16\end{array}$ \\
\hline RK99 & $1 \times 10^{7}$ & 10 & 110 & $\begin{array}{l}\mathrm{sor}^{+} \\
\mathrm{mal}^{+}\end{array}$ & $\begin{array}{r}28 \\
8\end{array}$ \\
\hline RK 107 & $1 \times 10^{9}$ & 8 & 250 & $\begin{array}{l}\mathrm{sor}^{+} \\
\mathrm{mal}^{+}\end{array}$ & $\begin{array}{l}31 \\
17\end{array}$ \\
\hline RK53* & $5 \times 10^{8}$ & 2 & 129 & $\begin{array}{l}\text { sor }^{\mathrm{m}} \\
\mathrm{mal}^{+}\end{array}$ & $\begin{array}{l}77^{*} \\
42\end{array}$ \\
\hline RK 119* & $2 \times 10^{8}$ & 10 & 230 & $\begin{array}{l}\text { sor }^{\mathrm{m}} \\
\mathrm{mal}^{+}\end{array}$ & $\begin{array}{l}22^{*} \\
17\end{array}$ \\
\hline
\end{tabular}

* Denotes mutation to use L-sorbose, when streaked on L-sorbose medium.

Induction of the new lysogens gave suspensions containing at least $10^{7}$ phage $\mathrm{ml}^{-1}$, which were used to transduce MW3016. Because strains RK53 and RK119 did not use L-sorbose, but mutated to use it, selection was made indirectly for sor by selecting for $m e t A^{+}$in all crosses (Table 6). Selection was also made separately for $\operatorname{proA}^{+}(6 \mathrm{~min})$, to check that the sor region was not transferred indiscriminately with donor markers. Transductants were tested for cotransduction of sor and $\mathrm{mal}^{+}$genes. The sor ${ }^{+}$genes from L-sorbose-positive strains showed $25 \%$ to $31 \%$ cotransduction with $\mathrm{met}^{+}$. Transductants receiving genes from L-sorbose-mutable donors were streaked on L-sorbose minimal medium and incubated for up to $14 \mathrm{~d}$ to see whether they gave Lsorbose-utilizing mutants; about $80 \%$ of the transductants derived from donor RK53, and $20 \%$ from RK119, gave mutants able to use L-sorbose. The pro $A^{+}$transductants neither grew, nor mutated to grow, on L-sorbose minimal medium.

\section{Inhibitory effects of L-sorbose}

Transduction of the Sor ${ }^{+}$character into K12 was unsatisfactory in two ways. Firstly, Sor ${ }^{+}$ transductants of K12 grew less well than the nine Sor $^{+}$wild strains when streaked on L-sorbose minimal medium; whereas wild strains gave uniform colonies of $2 \mathrm{~mm}$ diameter after $2 \mathrm{~d}$ on Lsorbose medium, the transductants required $5 \mathrm{~d}$ to give colonies which were not more than $2 \mathrm{~mm}$ and variable in diameter. Secondly, the average frequency of transduction of the Sor ${ }^{+}$character when selected directly was not more than $5 \%$ (and often much less) of the frequency of transduction of characters common to $\mathrm{K} 12$ and wild strains (such as pro $A^{+}$), regardless of whether transduction was from a wild strain to $\mathrm{K} 12$, or from a K12 (sor $\left.{ }^{+}\right)$hybrid to a K12 strain. In fact, transduction of sor ${ }^{+}$was more frequent when it was cotransduced with a nearby marker such as $\mathrm{met}^{+}$. These facts suggested that $\mathrm{K} 12\left(\mathrm{sor}^{+}\right)$bacteria lacked genes or alleles necessary for uniform and vigorous growth, or initiation of growth, on L-sorbose. One possibility was that Lsorbose might be partially inhibitory towards $\mathrm{K} 12$, the inhibition not being overcome by making the bacteria sor ${ }^{+}$except in so far as the L-sorbose was detoxified by metabolism. When K12 and L-sorbose-negative wild strains were streaked on lactate minimal medium supplemented with Lsorbose, L-sorbose proved to be partially inhibitory. In the absence of L-sorbose, uniform colonies of $2 \mathrm{~mm}$ diameter were obtained in $3 \mathrm{~d}$. In the presence of L-sorbose, colonies of each strain varied in size from 0.01 to $0.5 \mathrm{~mm}$ in diameter, except that RK31 and RK92 did not grow at all. The same degrees of inhibition occurred when acetate was the source of carbon and energy instead of lactate. 
L-Sorbose did not decrease growth of colonies in the presence of glucose or fructose, suggesting that catabolite repression annulled the inhibition. Inhibition did not occur in complex media lacking sugars, suggesting that other metabolites also relieved the inhibition. In auxanographic tests, 212 biochemical substances were tested on AB1621 bacteria on lactate minimal medium containing L-sorbose. About 3000 bacteria were spread on each plate and the plates were examined after $2 \mathrm{~d}$. Under these conditions the bacteria on control plates did not form visible colonies. Carbohydrates utilized by $\mathrm{AB} 1621$, namely glucose, fructose, trehalose, galactitol, rhamnose, ribose, mannose, L-fucose and sorbitol gave colonies of $2 \mathrm{~mm}$ diameter in their diffusion zones. Apart from sorbitol $\left(90 \mathrm{mg} \mathrm{l}^{-1}\right)$, the sugars and sugar alcohols that allowed growth in the presence of L-sorbose only did so at concentrations above $270 \mathrm{mg} \mathrm{l}^{-1}$, which supported significant growth in the absence of L-sorbose and lactate. Lactose, arabinose, galactose and other sugars not utilized by AB1621, did not give colonies. Two other substances were active, uridine and thymidine, and they gave colonies of $1 \mathrm{~mm}$ diameter. Uridine $\left(50 \mathrm{mg} \mathrm{l}^{-1}\right)$ and thymidine $\left(80 \mathrm{mg} \mathrm{l}^{-1}\right)$ in lactate medium containing L-sorbose each permitted vigorous growth of $\mathrm{K} 12$ strains and hybrids in the presence of L-sorbose. Uridine and thymidine also acted as sole sources of carbon and energy but did not support detectable growth (in the absence of L-sorbose) on plates at concentrations below $180 \mathrm{mg} \mathrm{l}^{-1}$.

Thus the low frequency of transduction of $\mathrm{sor}^{+}$probably resulted from the inhibitory effect of L-sorbose on recipient bacteria, before or after entry of donor DNA into the recipient's chromosome. This was confirmed in transduction experiments; when selection was made for pro $^{+}$, his $^{+}$, $\mathrm{met}^{+}$and $\mathrm{arg}^{+}$, the number of transductants decreased 100-fold when L-sorbose was present in the lactate (or acetate) minimal medium. Uridine $\left(50 \mathrm{mg} \mathrm{l}^{-1}\right)$, thymidine $\left(80 \mathrm{mg} \mathrm{l}^{-1}\right)$ and sorbitol $\left(90 \mathrm{mg}^{-1}\right)$, present with L-sorbose, each increased the frequency of all transductants from 1 per $5 \times 10^{7}$ phage to 1 per $2 \times 10^{6}$. Growth of recipient bacteria in T2 broth supplemented with sorbitol $\left(90 \mathrm{mg} \mathrm{l}^{-1}\right)$, before incubation with phage, increased the yield of sor ${ }^{+}$transductants selected on L-sorbose minimal medium by 10 -fold, but supplementation with uridine or thymidine had no effect. Unless stated otherwise, uridine $\left(50 \mathrm{mg} \mathrm{l}^{-1}\right)$ was routinely added to L-sorbose minimal medium.

\section{Two linked genes for L-sorbose utilization}

To obtain evidence about the number of genes involved in L-sorbose utilization, sor mutants were isolated from $\mathrm{K} 12\left(\right.$ sor $\left.^{+}\right)$hybrid Hfr MW5752, using $N$-methyl- $N^{\prime}$-nitro- $N$-nitrosoguanidine (MNNG) as mutagen. Of the 19 mutants obtained, 7 were stable and 12 mutated to use $L$ sorbose at frequencies of 1 per $10^{8}$ to 1 per $10^{10}$ bacteria plated. Mutants defective in catabolism of a carbohydrate often show inhibition by that carbohydrate (Yarmolinsky et al., 1959; Englesberg et al., 1962; Solomon \& Lin, 1972; Ferenci \& Kornberg, 1973; Lengeler, 1977). The mutants were therefore tested for inhibition by L-sorbose. Washed bacteria were seeded in lactate minimal agar (without supplements) to give about $2 \times 10^{6}$ bacteria ml-1 and a crystal of L-sorbose was applied to the solidified agar in each Petri dish. After $24 \mathrm{~h}$, seven mutants showed zones devoid of growth, $5 \mathrm{~cm}$ in diameter, around the crystals; the other mutants gave zones of inhibition characteristic of K12 strains. The tests were repeated with uridine, thymidine and sorbitol in the medium; they annulled the inhibitions at concentrations of 200,280 and $630 \mathrm{mg}$ $1^{-1}$, respectively, giving uniform growth throughout the plates. It seemed likely that there were two genes for L-sorbose utilization, one concerned with transport (gene sorT) and one with enzymic conversion to sorbitol 6-phosphate (gene sor $A$ ). The L-sorbose-sensitive mutants were provisionally classified as $\operatorname{sor}^{+} A$, and the rest as $\operatorname{sor} T A^{+}$(or $\operatorname{sorTA}$ ).

To test whether the mutations were in the sor region, P1 kc lysates of the mutants were used to transduce MW 3017 (met A sor ${ }^{+}$). Selection for met $A^{+}$gave about one transductant per $10^{6}$ phage in each cross. One hundred transductants from each cross were tested for ability to use L-sorbose. All crosses showed cotransduction of sor, at frequencies between 28 and $41 \%$. One met $^{+}$sor transductant from each cross was tested; each showed the same sensitivity to L-sorbose as its donor parent, and the same frequency of reversion to Sor ${ }^{+}$.

To make complementation tests, $F^{\prime}$ plasmids carrying each sor region were obtained from conjugations with the form: Hfr MWSN50 (ilv met $B^{+}$sor) $\times$recipient $\mathrm{JC1553}$ (leu his rpsL 
$\operatorname{rec} A \arg G m e t B$ ). Selection was made for early transfer of $m e t B^{+}$, usually transferred late by this $\mathrm{Hfr}$. Omitting isoleucine and valine from the plating medium, and adding streptomycin, gave selection against the donors. $F$ primes were chosen that carried the chromosomal region from $\mathrm{met}^{+}$to the $\mathrm{F}$ factor $(87-95 \mathrm{~min})$ including the sor region at $89.7 \mathrm{~min}$ and $\mathrm{mal}^{+}$at $91 \mathrm{~min}$. The presence of sor mutations in twelve of the $F^{\prime}$ transconjugants was confirmed by their ability to mutate to Sor ${ }^{+}$. At this stage it was not possible to show that sor regions were present in F primes derived from stable sor mutants. Partial diploids carrying all possible pairs of sor mutations were made by transfer of the $\mathrm{F}^{\prime}$ plasmids to the met $^{+}$sor transductants described above, in conjugations of the form: donor JC1553 (leu/F'sor malB ${ }^{+}$) $\times$recipient MWSN3050 (sor mal-3016), selection being made for $\mathrm{mal}^{+}$transconjugants. Transconjugants were purified by streaking, and then tested by streaking on L-sorbose minimal medium and incubating at $37^{\circ} \mathrm{C}$ for $60 \mathrm{~h}$. Parental donor and recipient strains, tested as controls, did not utilize L-sorbose, nor did partial diploids carrying the same mutation on plasmid and chromosome. When either replicon carried sor $^{+}$, it was expressed in the presence of any sor mutation. Complementation occured when the sor region from any of the mutants MWSN50, MWSN56, MWSN57, MWSN58, MWSN61, MWSN72 and MWSN78 (comprising the $\operatorname{sor}^{+} A$ group strongly inhibited by L-sorbose) was present with the sor region from five sor $T A^{+}$mutants, namely MWSN51, MWSN52, MWSN70, MWSN75 and MWSN77. Diploids carrying other pairs of mutant regions gave streaks composed largely of minute colonies, but with varying numbers of larger and late developing colonies up to $1.5 \mathrm{~mm}$ in diameter; the frequency and nature of the larger colonies was not determined, but they probably contained sor $^{+}$regions generated by crossing over.

\section{Sensitivity of two wild strains to L-sorbose}

Amongst the 29 Sor $^{-}$wild strains, 27 showed the low degree of sensitivity to L-sorbose shown by $\mathrm{K} 12$ and $\mathrm{K} 12$ (sorT $A^{+}$) mutants, but two showed high sensitivity typical of $\mathrm{K} 12\left(\operatorname{sor} T^{+} A\right)$ mutants. When seeded in lactate minimal agar and tested with crystals of L-sorbose, RK 32 and RK91 gave zones of complete inhibition $6 \mathrm{~cm}$ in diameter, and required uridine at 120 and $140 \mathrm{mg}^{-1}$ respectively to annul the inhibitions [compared with $200 \mathrm{mg} \mathrm{l}^{-1}$ for $\mathrm{K} 12\left(\operatorname{sor} T^{+} A\right)$ mutants]. It seemed that RK32 and RK91 might be naturally-occurring $\operatorname{sor}^{+} A$ strains. To test whether sensitivity was due to genes in the metA-malB region, P1clr100K M lysogens of the wild strains were prepared and their lysates used to transduce MW3016 (metA mal-3016), with selection for $\mathrm{metA}^{+}$. Amongst 200 transductants from each donor, $20 \%$ and $6 \%$, respectively, received $\mathrm{mal}^{+}$but no transductants displayed the high sensitivity of the donors.

\section{Genes for L-sorbose utilization}

In Klebsiella aerogenes, transport of $\mathrm{L}$-sorbose into the bacteria depends upon enzyme I of the phosphotransferase system and L-sorbose is phosphorylated to give L-sorbose 1-phosphate (Kelker et al., 1972). Reduction to sorbitol 6-phosphate is followed by oxidation by D-sorbitol-6phosphate dehydrogenase (EC 1.1.1.140) to D-fructose 6-phosphate. The latter is phosphorylated by phosphofructokinase (EC 2.7.1.11) to D-fructose 1,6-bisphosphate. Preliminary experiments showed that sor $^{+}$transductants were not obtained when using recipient strains carrying $p t s H$ (FF8020), ptsI (FF8040), pfkA (AM1) or crp (5333S) mutations.

To confirm the requirement for $p t s^{+}$gene function, pts mutants of MW871 were obtained, using MNNG and glucose tetrazolium indicator medium (Fraenkel \& Levison, 1967). After overnight incubation on the indicator medium, 5 dark red colonies were obtained amongst many pink ones; they gave poor growth on glucose, fructose and maltose and none on sorbitol and Lsorbose. To obtain evidence that the mutants were pts sor ${ }^{+}$, they were used as recipients in transduction with strain MW5 $\left(\mathrm{sac}^{+} \mathrm{pts} \mathrm{s}^{+}\right)$as donor. Genes $\mathrm{sac}^{+}$(sucrose utilization) and pts are $11 \%$ cotransducible (Alaeddinoglu \& Charles, 1979). Transductants able to use sorbitol were selected; they occurred with a frequency of 1 per $2 \times 10^{6}$ phage. Of 200 tested, all utilized Lsorbose and 18 utilized sucrose.

To confirm that L-sorbose utilization was dependent upon $p f k A^{+}$, the $p f k A$ mutation was transduced into MW4 (met $B$ pfk $A^{+}$sor ${ }^{+}$), using as donor AMl, and selecting for $m e t B^{+}$, which is $30 \%$ cotransducible with $p f k A$ (Vinopal et al., 1975). Transductants occurred with a frequency of 
1 per $2 \times 10^{6}$ phage. Of these, 50 were tested for cotransduction of $p f k A$ by streaking on fructose (20 mM) minimal medium; 13 used neither fructose nor L-sorbose, and 37 used both. The presence of sor in the 13 Sor $^{-}$transductants was confirmed by using each as donor in conjugation with AB1621; selection was made for Sor ${ }^{+}$transconjugants, and streptomycin was used to select against the donors.

Lengeler (1977) showed that $p f k A$ mutants accumulate fructose 6-phosphate, the accumulation being related to inhibition of growth by fructose, sorbitol and mannitol. If L-sorbose catabolism proceeds via fructose 6-phosphate, then $p f k A$ sor ${ }^{+}$bacteria presented with L-sorbose may suffer inhibition of growth on lactate. This was shown to be so by streaking on lactate minimal medium and on lactate minimal medium supplemented with L-sorbose.

Confirmation of a requirement for $c r p^{+}$was obtained by transducing the $c r p$ allele from 5333S into MW5 ( $\mathrm{sac}^{+}$metB sor $\left.{ }^{+}\right)$, and selecting for the streptomycin resistance allele $r p s L(0.3 \mathrm{~min}$ from crp: Epstein \& Kim, 1971) after incubating the phage-infected bacteria $\left(30^{\circ} \mathrm{C}, 24 \mathrm{~h}\right)$ in 10 $\mathrm{ml}$ complete broth, to allow phenotypic expression of resistance. About $30 \%$ of the $r p s L$ transductants behaved as $c r p$ in being able to utilize glucose and fructose, but not lactose, galactose, arabinose, xylose, sucrose or L-sorbose.

\section{Mutability and complementation tests with wild strains}

The 29 Sor- $^{-}$wild strains were tested for mutability to Sor ${ }^{+}$using nine chemical mutagens including $\mathrm{MNNG}$, but no mutant colonies were found.

Hill (1980) used $\mathrm{F}$ primes to demonstrate that sucrose-negative wild strains often possessed one or other of the sac genes in plus form. The $\operatorname{sor} T^{+} A^{+}$, sor $T^{+} A$ and $\operatorname{sor} T A^{+}$primes were used to test whether any Sor- wild strains were $T^{+}$or $A^{+}$. First it was shown that each of the 29 Sor $^{-}$wild strains was able to receive and express the $s o r^{+}$genes. $\mathrm{JC1} \mathrm{s53} / \mathrm{F}^{\prime} \mathrm{sor}^{+}$served as donor in conjugations; selection was made on L-sorbose minimal medium containing uridine $\left(50 \mathrm{mg} \mathrm{l}^{-1}\right.$, but $200 \mathrm{mg} \mathrm{l}^{-1}$ for RK32 and RK119). Selection against the donor was done by omitting leucine, histidine, arginine and methionine from the medium. All the wild strains gave Sor ${ }^{+}$transconjugants, at frequencies between 1 per $5 \times 10^{2}$ and 1 per $3 \times 10^{7}$ donors; for $\mathrm{AB} 1621$ the frequency was 1 per $3 \times 10^{2}$. The conjugations were repeated using JC1553 strains carrying four different F primes: two carried $\operatorname{sor} T^{+} A$ primes and two carried sor $T A^{+}$primes. Plates were incubated for $10 \mathrm{~d}$ at $30^{\circ} \mathrm{C}$. No Sor ${ }^{+}$colonies developed.

The sor $T^{+} A^{+}$prime was transferred to two strains of Salmonella typhimurium, one of Shigella flexneri, one of Klebsiella aerogenes and to two other unidentified wild strains of Klebsiella. The frequencies of transfer were from 1 per $5 \times 10^{5}$ to 1 per $10^{8}$ donors. Sor ${ }^{+}$colonies grew to about $2.5 \mathrm{~mm}$ diameter after $3 \mathrm{~d}$ at $37^{\circ} \mathrm{C}$, except that the Shigella colonies grew much more slowly to about $1 \mathrm{~mm}$ diameter.

\section{DISCUSSION}

The eight sor regions all occupied approximately the same positions in their respective donors, relative to genes within cotransduction distance, though the experiments would not reveal minor differences of gene order. Transduction of sor into $E$. coli $\mathrm{K} 12$ does not imply homology between the incoming sor genes and the corresponding region in $\mathrm{K} 12$, but indicates some homology in regions extending about $2 \mathrm{~min}$ on either side of sor. For different wild donors the frequencies of transduction were rather similar, as were the frequencies of cotransduction and the frequencies in exchanges between $\mathrm{K} 12$ and $\mathrm{K} 12\left(\right.$ sor $\left.^{+}\right)$hybrids, indicating that the homology between wild donors and $\mathrm{K} 12$ was considerable. The sor genes themselves did not noticeably obstruct crossing-over with the K 12 chromosome, suggesting that they were not associated with long tracts of DNA non-homologous with K12. If sor was associated with considerable non-homology, fragments transduced into K12 might persist as exogenote fragments. Of transductants selected to be Sor ${ }^{+}$(Table 3), less than $10 \%$ gave evidence of instability for sor ${ }^{+}$, and they may have been partial diploids, or lysogens containing specialized transducing phage: the rest displayed recessive donor characters and must have contained haploid recombinant regions.

The requirement for gene $c r p^{+}$shows that the $s o r^{+}$genes are subject to catabolite repression control. This indicates compatibility of the sor $^{+}$control regions with $\mathrm{K} 12$ catabolite repression 
protein, unless the successful transductions from wild strains entrain sor ${ }^{+}$genes with $\mathrm{K} 12$ control regions.

The $\mathrm{Sor}^{+}$character was generated by at least two closely linked genes; $\operatorname{sor} \mathrm{T}^{+}$probably specifies an L-sorbose permease and sor $\mathrm{A}^{+}$an L-sorbose-1-phosphate reductase.

Kelker et al. (1972) showed that in Klebsiella aerogenes, L-sorbose catabolism requires a sorbitol-6-phosphate dehydrogenase activity. Escherichia coli $\mathrm{K} 12$ possesses an inducible sorbitol-6-phosphate dehydrogenase, encoded by the gene $s r l D$ (Lengeler \& Lin, 1972). This may explain the fact that sorbitol annulled the partial inhibition of Sor- bacteria by L-sorbose; sorbitol may have induced sorbitol dehydrogenase, thereby completing a pathway for L-sorbose metabolism. Lengeler (1977) reported that intracellular accumulation of fructose 6-phosphate is the cause of inhibition of $p f k A$ mutants growing in the presence of fructose, sorbitol and mannitol. L-sorbose also inhibited $p f k A$ sor $^{+}$strains, suggesting that it is also converted to fructose 6-phosphate.

Defects in catabolism of a carbohydrate, after phosphorylation and intracellular accumulation, often cause the carbohydrate to become inhibitory (Yarmolinsky et al., 1959; Englesberg et al., 1962; Solomon \& Lin, 1972; Ferenci \& Kornberg, 1973; Lengeler, 1977). Uridine and thymidine overcame the inhibition by L-sorbose, at concentrations indicative of action as substrates rather than cofactors, and must offer a clue about the mechanism of inhibition. Inhibition might result from incomplete or incorrect metabolism of L-sorbose by enzymes normally acting on other sugars, and might lead to irreversible combination of a nucleoside cofactor with L-sorbose, or a phosphorylated derivative, or to irreversible phosphorylation of a nucleotidyl transferase. Nucleosides might relieve the inhibition by replenishing the cofactor or serving as further acceptors of phosphate.

The $\mathrm{sac}^{+}, \mathrm{rll}^{+}, \mathrm{atl}^{+}$and $\mathrm{gat}^{+}$genes, which are also found in some wild strains but not others, all have characteristic locations (Hill \& Charles, 1980; Woodward \& Charles, 1980 b): the sor ${ }^{+}$ genes similarly occupy a characteristic region of the chromosome. One may conceive an ideal linkage map for a species, with each existing strain exhibiting only a sample of genes from the ideal map. To what extent the genes in wild strains may be transposed from their position in the ideal map is an important question for investigation.

If selective forces do not act to maintain linkage relations, then the expectation is that genes in different lineages will evolve different linkage relations. Genetic exchange may be the only force capable of conserving linkage relations in E. coli. The most likely mechanism of gene transfer, transduction and plasmid-mediated conjugation, could only conserve linkage relations over short distances. Genetic exchange need not be frequent, compared with asexual reproduction, provided that occasionally it conferred selective advantage on some progeny.

About $40 \%$ of the wild strains examined were Sor ${ }^{+}$. Similar polymorphisms exist for many characters. The frequencies observed in this laboratory are often surprisingly similar to those recorded by Edwards \& Ewing (1972) for rather different circumstances. It seems increasingly likely that the proportions of positives and negatives may be balanced at particular ratios for given characters. Why do such polymorphisms exist? The positive and negative morphs of a given character might be selectively neutral, within sexually integrated populations. Alternatively, wild strains might constitute genetically isolated lineages with, for example, the Sor morphs being either neutral or adaptive. On the other hand, the genes generating the different morphs might flow through E. coli (and perhaps close relatives or even distinct organisms sharing the same ecological niches) as a result of sexual reproduction, providing balancing selective effects, either continuously or on different occasions. This would mean that the variation represents genetical polymorphism (Ford, 1971). If so, the possibility emerges of a fruitful synthesis between the study of populations of bacteria and that of populations of higher organisms.

We express our appreciation to those who have sent cultures, especially Dr B. J. Bachmann. M. J. W. was in receipt of a Science Research Council research studentship. Much of the information presented is from the Ph.D. thesis of M. J.W. (Woodward, 1980). 


\section{REFERENCES}

Adelberg, E. A., Mandel, M. \& Chen, G. C. C. (1965). Optimal conditions for mutagenesis by $\mathrm{N}$ methyl- $N^{\prime}$-nitro- $N$-nitrosoguanidine in Escherichia coli K12. Biochemical and Biophysical Research Communications 18, 788-795.

Alaeddinoglu, N. G. \& Charles, H. P. (1979). Transfer of a gene for sucrose utilization into Escherichia coli $\mathrm{K} 12$, and consequent failure of expression of genes for D-serine utilization. Journal of General Microbiology $110,47-59$.

BACHMANN, B. J. \& Low, K. B. (1980). Linkage map of Escherichia coli K12, edition 6. Microbiological Reviews 44, 1-56.

Brice, C. B. \& Kornberg, H. L. (1968). Genetic control of isocitrate lyase activity in Escherichia coli. Journal of Bacteriology 96, 2185-2186.

BUKHARI, A. I. \& TAYLOR, A. L. (1971). Genetic analysis of diaminopimelic acid and lysine requiring mutants of Escherichia coli. Journal of Bacteriology 105 , 844-854.

Clark, A. J. \& MARguiles, A. D. (1965). Isolation and characterization of recombination deficient mutants of Escherichia coli K12. Proceedings of the National Academy of Sciences of the United States of America 53, 45l-459.

Coetzee, J. N. (1962). Sucrose fermentation by Proteus hauseri. Journal of General Microbiology 29, 455-472.

Colson, C., Glover, S. W., Symonds, N. \& Stacey, K. A. (1965). The location of the genes for host controlled modification and restriction in Escherichia coli K12. Genetics 52, 1043-1050.

EDWARDS, P. R. \& EWING, W. H. (1972). Identification of Enterobacteriaceae, 3rd edn. Minneapolis : Burgess Publishing.

EgGertson, G. \& Adelberg, E. A. (1965). Map positions and specificities of supressor mutations in Escherichia coli K12. Genetics 52, 319-340.

Englesberg, E., ANderson, R., Weisberg, N., Lee, P., Huttenhauer, G. \& Boyer, H. (1962). L-Arabinose-sensitive, L-ribulose-5-phosphate-4-epimerase deficient mutants of Escherichia coli. Journal of Bacteriology 84, 137-146.

EPSTEIN, W. \& KIM, B. S. (1971). Potassium transport loci in Escherichia coli K12. Journal of Bacteriology 108, 639-644.

EPSTEIN, W., JewetT, S. \& Fox, C. F. (1970). Isolation and mapping phosphotransferase mutants in Escherichia coli. Journal of Bacteriology 104, 793-797.

FERENCI, T. \& KoRNBERG, H. L. (1973). The utilization of fructose by Escherichia coli. Properties of a mutant defective in fructose-1-phosphate kinase. Biochemical Journal 132, 341-347.

ForD, E. B. (1971). Ecological Genetics, 3rd edn. London: Chapman \& Hall.

Fraenkel, D. G. \& Levisohn, S. R. (1967). Glucose and gluconate metabolism in an Escherichia coli mutant lacking phosphoglucoseisomerase. Journal of Bacteriology 93, 1571-1578.

Goldberg, R. B., Bender, R. A. \& Streicher, S. L. (1974). Direct selection for P1-sensitive mutants of enteric bacteria. Journal of Bacteriology 118, 810814.

Hill, S. H. (1980). Genetic analysis of variation in
Escherichia coli. Ph.D. thesis, Reading University, U.K.

Hill, S. H. \& Charles, H. P. (1980). Genetical analysis of natural variation in sucrose utilization in Escherichia coli. Society for General Microbiology Quarterly 7, 82.

Hofnung, M., Hatfield, D. \& Schwartz, M. (1974). The malB region in Escherichia coli K12: characterization of new mutations. Journal of Bacteriology 117, 40-47.

Huang, M. \& PitTard, J. (1967). Genetic analysis of mutant strains of Escherichia coli requiring p-aminobenzoic acid for growth. Journal of Bacteriology 93, 1938-1942.

KADNER, R. J. \& Liggins, G. L. (1973). Transport of vitamin B12 in Escherichia coli: genetic study. Journal of Bacteriology 115, 514-521.

Kawasaki, T., Nakata, T.\& Nose, Y. (1968). Genetic mapping with a thiamine requiring auxotroph of $E s$ cherichia coli $\mathrm{K} 12$ defective in thiamine phosphate pyrophosphorylase. Journal of Bacteriology 95, 14831485.

Kelker, N. E., Simkis, R. A. \& Anderson, R. L. (1972). Pathway of L-sorbose metabolism in Aerobacter aerogenes. Journal of Biological Chemistry 247, 1479-1483.

LENGELER, J. (1977). Analysis of mutations affecting the dissimilation of galactitol in Escherichia coli K12. Molecular and General Genetics 152, 83-91.

Lengeler, J. \& LiN, E. C. C. (1972). Reversal of the mannitol-sorbitol diauxie in Escherichia coli. Journal of Bacteriology 112, 840-848.

McConville, M. L. \& Charles, H. P. (1979). Isolation of haemin-requiring mutants of Escherichia coli K12. Journal of General Microbiology 113, 155-164.

Morrisey, A. T. E. \& FraenKel, D. G. (1968). Selection of fructose-6-phosphate kinase mutants of Escherichia coli. Biochemical and Biophysical Research Communications 33, 467-473.

Pittard, J., Loutit, J. S. \& Adelberg, E. A. (1963). Gene transfer by $\mathrm{F}$ prime strains of Escherichia coli K12. I. Delay in initiation of chromosome transfer. Journal of Bacteriology 85, 1394-1401.

ReEves, P. (1959). Studies in bacterial genetics. Ph.D. thesis, London University, U.K.

Salisbury, V., Hedges, R. W. \& Datta, N. (1972). Two modes of curing transmissible bacterial plasmids. Journal of General Microbiology 70, 443-452.

SCHELl, J. \& Glover, S. W. (1966a). The effect of heat on host controlled restriction in Escherichia coli of phage lambda. Journal of General Microbiology 45, 61-72.

Schell, J. \& Glover, S. W. (1966b). On the localization of a factor responsible for host controlled restriction in Escherichia coli P1. Genetical Research 7, 277-279.

SCHELl, J. \& Glover, S. W. (1966c). The effect of various physiological conditions on host controlled restriction in Escherichia coli P1. Genetical Research 7, 273-276.

Solomon, E. \& LiN, E. C. C. (1972). Mutations affecting the dissimilation of mannitol by Escherichia coli K12. Journal of Bacteriology 111, 566-574. 
Stouthamer, A. H., De HaAn, P. G. \& Nijkamp, H. J. J. (1965). Mapping of purine markers in Escherichia coli K12. Genetical Research 6, 442-453.

Tomoeda, M., INUZUKa, M., KUbo, N. \& NAKamURA, S. (1968). Effective elimination of drug resistance and sex factors in E. coli by sodium dodecyl sulphate. Journal of Bacteriology 95, 1078-1089.

VANDERWinKel, E. \& DeVlieghere, M. (1968). Physiologie et génétique de l'isocitratase et des malate synthases chez Escherichia coli. European Journal of Biochemistry 5, 81-90.

Vinopal, R. T., Clifton, D. \& Fraenkel, D. G. (1975). pfkA locus of Escherichia coli. Journal of Bacteriology 112, 1162-1171.

WoOD, W. B. (1966). Host specificity of DNA produced by Escherichia coli: bacterial mutations affecting the restriction and modification of DNA. Journal of Molecular Biology 16, 118-133.
WOODWARD, M. J. (1980). Genetic analysis of variation in Escherichia coli. Ph.D. thesis, Reading University, U.K.

Woodward, M. J. \& Charles, H. P. (1980a). Introduction of genes for sorbose utilization into Escherichia coli K12. Society for General Microbiology Quarterly $7,81$.

Woodward, M. J. \& Charles, H. P. (1980 b). Genes for ribitol and arabitol utilization, and genes for galactitol utilization, behave as chromosomal alternatives. Society for General Microbiology Quarterly 7, 82.

Yarmolinsky, M. E., Weismeyer, H., Kalckar, H. M. \& JORDAN, E. (1959). Hereditary defects in galactose metabolism of Escherichia coli mutants. II. Galactose induced sensitivity. Proceedings of the National Academy of Sciences of the United States of America 45, 1786-1791. 